\title{
A Rare Complication: Blue Urine Developed After Laparoscopic Chromopertubation
}

\section{Laparoskopik Tubal Geçirgenlik Kontrolü Sonrasında Mavi İdrar}

\section{Duygu Uçar ๑, Burcu Artunc Ulkumen $\odot$}

Cite as: Uçar D, Artunc Ulkumen B. A rare complication: blue urine developed after laparoscopic chromopertubation. Forbes J Med. 2021;2(1):54-7.

\section{ABSTRACT}

Methylene blue is a dye that is widely used in medicine. The underlyin reason this widespread use is that it is easily accessible, inexpensive and safe. Although rarely seen, some complications may develop during use of methylene blue. It is important that clinicians should be aware of these unwanted conditions, recognize these complications at an earlier stage, and take suitable measures.

Keywords: blue urine, laparoscopy, tubal patency, methylene blue

Öz

Metilen mavisi, tıpta yaygın kullanım alanına sahip bir boyadır. Ayrıca, kolayca ulaşılabilir olması, ucuz ve güvenli olması, yaygın kullanımındaki başlıca nedenlerdir. Ancak, nadiren de olsa metilen mavisi kullanımı sonrasında bazı komplikasyonlar gelişebilmektedir. klinisyenlerin bu istenmeyen durumlardan haberdar olup, komplikasyonları erken tanıması ve uygun önlemleri alması önemlidir.

Anahtar Kelimeler: mavi idrar, laparoskopi, tubal geçirgenlik, metilen mavisi
Received/Gelis: 29.12 .2020

Accepted/Kabul: 08.01.2021

Publication date: 27.04 .2021

Sorumlu Yazar/

Corresponding Author:

Burcu Artunc Ulkumen

Celal Bayar Üniversitesi, Kadın Hastalıkları ve Doğum Anabilim Dalı,

Manisa - Türkiye

artunc.burcu@gmail.com

ORCID: 0000-0002-3128-8751

D. Uçar 0000-0003-4751-5944

Celal Bayar Üniversitesi, Kadın Hastalıkları ve Doğum AD, Manisa - Türkiye 


\section{INTRODUCTION}

Methylene blue is an inexpensive and reliable dye that is widely used in gynecology. It has different areas of use, including the chromopertubation procedure to evaluate the tubal patency in infertile patients. In addition to being a staining material, it is used as an antiseptic in the genitourinary system, as a topical agent with polychromatic light in some viral infections (herpes simplex virus), and in the treatment of urolithiasis in combination with ascorbic acid. ${ }^{1}$

It should be kept in mind that methylene blue, like all drugs, can have side effects and drug interactions. Ramin et al. reported that the use of methylene blue is safer compared to other blue dyes. ${ }^{2}$

However, there have been reported cases of methemoglobinemia and / or allergic reactions in patients who underwent laparoscopic chromopertubation. 3 These patients have demonstrated a variable range of signs and symptoms ranging from bluish staining of body fluids to anaphylactic shock.

Methylene blue contains four heme groups with reduced iron $(+2)$ under normal conditions of hemoglobin. When hemoglobin is oxidized, it transforms into methemoglobin form that cannot bind to oxygen. This transformation occurs as a result of the oxidation of the iron in its content from +2 to +3 . Methemoglobin cannot bind to oxygen, and this causes tissues to remain oxygen free. As a result, hypoxia, anemia, even metabolic acidosis and death may occur.

Methemoglobin formation in healthy individuals is in a balance and the level of methemoglobin is less than $1 \%$ of the total hemoglobin value thanks to the protection provided by endogenous mechanisms.4 However, even normal levels of methylene blue can be dangerous in those with G-6PD deficiency, cardiovascular disease or anemia. These protective mechanisms may also be insufficient due to drugs or exposure to high doses of methylene blue. Interestingly, methylene blue converts methemoglobin back to hemoglobin by exerting the opposite effect at low concentration. Therefore, methylene blue is also accepted as a treatment for methemoglobin.

The diagnosis is made by co-oximetry (photopectrometry). In this process, support is obtained from pulse oximetry and arterial blood gas analyzers. The higher the percentage of methemoglobin, the more severe the symptoms and clinical findings. Primary treatment is supportive care. In cases where it is not sufficient, oral or IV methylene blue can be given.

\section{CASE REPORT}

Thirty-seven year-old female patient, who could not conceive before, had a child request for 2.5 years. We could not find any pathology that would prevent her from getting pregnant in her examinations and tests. After that, laparoscopic chromopertubation was planned for the patient under general anesthesia due to primary infertility. Methylene blue was used to show tubal transition during the procedure. Uterus and adnexal areas were noted as usual. A total of $20 \mathrm{mg}$ of methylene blue at a concentration of $0.5 \mathrm{mg} / \mathrm{ml}$ was administered into the cavity through a uterine manipulator. Simultaneously, free shedding was observed from the bilateral fimbrial end. The procedure was completed without any problem and the patient was followed up postoperatively.

In the postoperative follow-ups, it was observed that the patient's urine turned blue. The patient's vitals were stable as follows: pulse rate: $80 / \mathrm{min}$, blood pressure: $125 / 85 \mathrm{mmHg}, \mathrm{O}_{2}$ saturation: $99 \%$. No abnormal parameter was found in the arterial blood gas taken from the patient. Oxygen saturation was monitored closely and oxygen support was planned when necessary. Urine output of the patient, whose vitals were not impaired, remained within normal limits despite blue color of urine. The urine color started to lighten on the first day of the postoperative period and returned to normal completely on the second postoperative day. There was no need for any intervention in the patient whose general condition was good and vital signs were stable. The patient, who did not have any problems in the follow-up, was discharged on the second postoperative day without any problem. 


\section{DISCUSSION}

The severity of symptoms due to methemoglobinemia increases as hypoxia deepens. The situation that caused methemoglobinemia should be eliminated as soon as possible. Mild symptoms regress successfully with simple measures, supportive treatment, and close follow-up. However, severe symptoms can rapidly worsen the clinical course. In this case, methylene blue can be administered orally or IV. Acceptable toxic levels with this treatment are reached at $7 \mathrm{~mL} / \mathrm{kg} .5$

In our case, $20 \mathrm{mg}$ of methylene blue was used at a concentration of $0.5 \mathrm{mg} / \mathrm{ml}$. Despite this very low concentration, methemoglobinuria developed. No pathology was found in the patient that would cause this complication to occur. She had no known disease and had never developed a reaction to a drug before.

In the literature, it was reported that a patient with pelvic tuberculosis had blue urine for six days after an operation performed using methylene blue. 6 Cases of systemic anaphylaxis, pulmonary edema and inflammatory peritonitis have been also reported after the use of methylene blue in laparoscopic chromopertubation.7,8 Dewachter et al., cutaneous test positivity, confirmed an anaphylactic reaction against methylene blue based on positive skin tests .9

Considering the common characteristics of the reported cases, it seems likely that blue urine will appear in the presence of an infection that causes obstruction of the tubes (pelvic tuberculosis, PID) or as a mild symptom of systemic anaphylaxis. However, there was no underlying disease in our patient that could explain the formation of blue urine. It is thought that methylene blue used in small amounts under these conditions is extravasated from the pelvic cavity to the bladder.

Even if it is considered relatively safe, it should be kept in mind that complications may develop against all drugs used. This includes methylene blue, which is commonly used in infertile patients. Blue urine may be a precursor to a possible systemic anaphylaxis. If a process that can be overcome with oxygen support and supportive treatment is overlooked, then it may be possible to enter an irreversible path.

For this reason, clinicians should keep in mind that use of methylene blue may also have complications and they should be alert to signs of its toxicity. Only with this approach an early diagnosis can be made and possible worse consequences can be prevented.

Çıkar Çatışması: Yoktur.

Finansal Destek: Yoktur.

Hasta Onamı: Alındı.

Conflict of Interest: None.

Funding: None.

Informed Consent: Receipt.

\section{REFERENCES}

1. Clifton J, Leikin JB. (2003). Methylene Blue. American Journal of Therapeutics, 10(4), 289-291. doi: 10.1097/00045391-200307000-00009

2. Ramin S, Azar FP, Malihe H. Methylene blue as the safest blue dye for sentinel node mapping: emphasis on anaphylaxis reaction Acta Oncol, 50 (2011), pp. 729-731. doi: 10.3109/0284186X.2011.562918

3. Akazawa M, Wu Y-H, Liu W-M. (2019). Allergy-like reactions to methylene blue following laparoscopic chromopertubation: A systematic review of the literature. European Journal of Obstetrics \& Gynecology and Reproductive Biology. doi:10.1016/j.ejogrb.2019.03.019

4. Cortazzo JA, Lichtman AD. (2014). Methemoglobinemia: A Review and Recommendations for Management. Journal of Cardiothoracic and Vascular Anesthesia, 28(4), 1043-1047. doi: 10.1053/j.jvca.2013.02.005

5. Groeper K, Katcher K, Tobias JD. (2003). Anesthetic Management of a Patient with Methemoglobinemia. Southern Medical Journal, 96(5), 504-509. doi: 10.1097/01.smj.0000051342.99317.99

6. MhaskarR,MhaskarA.(2002).Methemoglobinemia following chromopertubation in treated pelvic tuberculosis. International Journal of Gynecology \& Obstetrics, 77(1), 41-42. doi: 10.1016/s0020-7292(01)00574-4

7. Nolan DG. Inflammatory peritonitis with ascites after methylene blue dyechromopertubation during diagnostic laparoscopy. J Am Assoc Gynecol Laparosc. 995;2(4):483-5. doi: 10.1016/s1074-3804(05)80076-3

8. Millo T, Mishra R, Giridhar S, Rajutji R, Lalwani $S$, Dogra TD. Fatal pulmonary oedema following 
D. Uçar and B. Artunc Ulkumen, Blue urine after Laparoscopic Chromopertubation

laparoscopic chromopertubation. national journals of India. 2006;19(2):78-9. Available from: https:// pubmed.ncbi.nlm.nih.gov/16756195/

9. Dewachter P, Mouton-Faivre C, Trechot P, Lleu JC, Mertes PM. Severe anaphylactic shock with methylene blue instillation. Anesth Analg. 2005;101:149-50.

doi: 10.1213/01.ANE.0000153497.60047.80 